\title{
Determination of Tannins and Sulfur Dioxide Content of Different Wine Samples by Titrimetric Method
}

\author{
KHUDBUDIN MULANI, NUTAN PAWAR, NIRAJ NIRHALI and VARSHA RATHOD*
}

Directorate of Forensic Science Laboratories, Kalina, Santacruz (E), Mumbai-400098, India varsha_rathod@hotmail.com

Received 10 January 2016 / Accepted 8 February 2016

\begin{abstract}
Tannins are the substances that can be found in plants like tea, citruses, apple, pear, plum, coffee, cocoa and grapes. Tannin is a natural ingredient of wines whereas, sulfur dioxide, in contrast, and is an essential additive added to all wines. It acts as an antioxidant and prevents attack of unwanted bacteria and yeast. In this study we have analyzed twelve wine samples for tannins as well as sulfur dioxide content. There are several methods used for determination of tannins and sulfur dioxide content even though the titration method plays an important role. Redox titration method was used for determination of tannins content and Ripper method for sulfur dioxide content. Tannins content were found in the range of 0.016 to $0.25 \%$ while free and combine: sulfur dioxide content is in the range of 4.78 to $12.5 \mathrm{ppm}$ and 64 to $256 \mathrm{ppm}$ respectively.
\end{abstract}

Keywords: Tannins, Sulfur dioxide, Wine, Titration

\section{Introduction}

Wines are obtained from the total or partial alcoholic fermentation of crushed grapes and grape musts. In the fermentation process, sugar present in the grapes gets converted into ethanol by anaerobic action of yeast. The phenolic compounds, more specific tannins are most important constituent in the grapes and wine. It plays very important role in oxidation reaction of the maturation and aging of wine as well as organoleptic properties. They are also responsible for all the differences in color and taste, especially in red wines. Oberholster described that, the phenolic composition of wine does not depend on wine making condition only ${ }^{1}$. Distribution of phenolic compounds in grapes is $1 \%$ in the pulp, $5 \%$ in the juice, $30-50 \%$ in the skin and rest of phenol in seeds ${ }^{2}$.

The color of the wine is due to presence of a class of flavonoids ${ }^{3}$. Tannins are a collective name for colorless but bitter flavonoids. Tannins can be divided into two groups namely the hydrolysable tannins and condensed tannins ${ }^{4}$. Hydrolysable tannins are easily oxidized and thereby decreasing the oxygen availability for the reaction. It also has ability to inhibit the growth of several wood decaying fungi ${ }^{5}$. Whereas condensed tannins does not significantly affect the chemical age and color intensity of the wine but external addition of these tannins increase total phenols of the tannin ${ }^{6}$. 
Tannins are also known to precipitate protein, inhibit digestive enzyme and affect the utilization of vitamin and minerals ${ }^{7}$. Due to this anticarcinogenic effect of tannins, this work was carried out to know how much percent of tannins are present in various wine samples. There are several methods used to determine tannin contents in wines, of which Prussian blue and Folin method as well as Vanillin and acid-butanol assay are well known ${ }^{8-11}$. Besides these methods titration methods plays important role in laboratory scale analysis of tannins. The standard solution of potassium permanganate is used to oxidize the tannins and other coloring matter ${ }^{12}$.

Sulfur dioxide, in contrast, is an essential additive to all wines because certain amount of sulfur dioxide prevents the wine deteriorating and becoming incompatible. It destroys bacteria and also acts as an antioxidant. The wine with less amount of sulfur dioxide present may suffer from biocidal attack. On the other hand if too much sulfur dioxide would impart unpleasant taste. The legal limits for the total sulfur dioxide are varying from country to country but most commonly accepted value for total sulfur dioxide is $250 \mathrm{ppm}$. In India legal limit for total sulfur dioxide content is $450 \mathrm{ppm}^{13}$. Normally $20-40 \mathrm{ppm}$ level of free sulfur dioxide does not affect on the taste of wine. In this article we analyze twelve various brands of wine samples for tannins as well as sulfur dioxide content by simple titration method.

\section{Experimental}

Oxalic acid, potassium permanganate, sodium hydroxide and sulfuric acid were purchased from Merck, and used as received. Starch and iodine procured from Thomas Baker and were used without purification. Indigo caramine and activated charcoal were purchased from Molychem Pvt. Ltd and used without purification.

For the preparation of $0.004 \mathrm{M} \mathrm{KMnO}_{4}$ solution, $0.158 \mathrm{~g}$ of $\mathrm{KMnO}_{4}$ was dissolved in $100 \mathrm{~mL}$ of distilled water and then diluted up to $250 \mathrm{~mL}$ with distilled water. The indicator indigo caramine $(0.5 \%)$ was made by dissolving $0.5 \mathrm{~g}$ of indigo caramine in $60 \mathrm{~mL}$ of warm distilled water. The solution is cooled to room temperature, $4 \mathrm{~mL}$ of concentrated sulfuric acid is added and then diluted up to $100 \mathrm{~mL}$ with distilled water. This solution was filtered by Whatman filter paper number 42 . The iodine solution was prepared by dissolving $1.27 \mathrm{~g}$ of iodine and $2.0 \mathrm{~g}$ of potassium iodide in distilled water and diluted up to $50 \mathrm{~mL}$ with same solvent. Both potassium permanganate and iodine solutions were standardized with oxalic acid and sodium thiosulfate respectively.

\section{Methods}

\section{Determination of tannin contents}

$5 \mathrm{~mL}$ of wine sample was pipetted out in a conical flask and $10 \mathrm{~mL}$ of distilled water was added. This solution was heated on water bath until volume of wine and water was reduced to $5 \mathrm{~mL}$. To this conical flask, $10 \mathrm{~mL}$ of distilled water and $2 \mathrm{~mL}$ of $0.5 \%$ indigo caramine indicator was added. The above solution was titrated with $0.004 \mathrm{M} \mathrm{KMnO}_{4}$ solution. The color changes was noted; golden yellow color is the end point. The consumed volume of $\mathrm{KMnO}_{4}$ was recorded as back titration reading (A). Blank titration was carried out with $25 \mathrm{~mL}$ of wine sample and $1 \mathrm{~g}$ of charcoal, stirring thoroughly and kept aside for 15 minutes. $5 \mathrm{~mL}$ of above decolorized wine sample was pipetted out in conical flask and continued the procedure as applied for back titration. The consumed volume of $\mathrm{KMnO}_{4}$ was recorded as blank titration reading (B).

The amount of potassium magnate used in oxidation of tannins can be calculated as A$\mathrm{B}=\mathrm{C} \mathrm{mL}$. The standard tannin solution for which $1 \mathrm{~mL}$ of $0.004 \mathrm{M} \mathrm{KMnO}_{4}=0.0832 \mathrm{mg}$ of tannin. Therefore, percent of tannins in wine $=0.01664 \times \mathrm{C}$. 


\section{Determination of sulfur dioxide content}

\section{Free sulfur dioxide}

$50 \mathrm{~mL}$ of wine sample was pipetted out into a conical flask. $5 \mathrm{~mL}$ of $25 \%$ sulfuric acid and 2-3 drops of starch indicator was added. The above solution was titrated with $0.01 \mathrm{M}$ iodine solution until blue color appeared.

\section{Total sulfur dioxide}

$25 \mathrm{~mL}$ of $1 \mathrm{M}$ sodium hydroxide solution was pipetted out into a conical flask containing $50 \mathrm{~mL}$ of wine sample, shaked well and left the flask for 15 minutes. To this flask $10 \mathrm{~mL}$ of $25 \%$ sulfuric acid and 2-3 drops of starch indicator was added. The above solution was titrated with $0.01 \mathrm{M}$ iodine solution until blue color appeared. Amount of sulfur dioxide= $12.8 \times \mathrm{mL}$ of iodine used.

\section{Results and Discussion}

Tannins are the substances found especially in red wines. Red wines are made by crushing dark red and black grapes. It includes whole grape, skin and seeds. On the other hand, white wines are made by white grapes and it does not include skin and seeds. The skin adds color and flavor to red wines and this is the reason why red wines are having more tannins content. The level of tannins in white wine is only about one tenth of that found in red wine.

The results for tannins and sulfur dioxide content in various types of wine samples have been summarized in Table 1. It was found that tannins content are in the range of 0.016 to $0.25 \%$. Difference in the tannins content may be due to difference in the process of manufacturing, raw material used and the aging of wine. The concentration of tannins affects especially taste properties of wine, but concentration of these compounds are too low to contribute the taste of wine has been described by Somers ${ }^{14}$. In case of oak aged wines, concentration of tannins is very low due to several reasons; toasting is one of them. Toasting of the barrels reduces the tannins content because toasting influences the extraction of tannins. In the toasting process, elligitannins also undergoes chemical transformation due to oxidation, polymerization and hydrolysis of wine ${ }^{15}$. Another reason for low concentration of tannins content in the wine may be due to precipitation of tannins during barrel fermentation and low aging period ${ }^{16}$.

Table 1. Tannins and sulfur dioxide content of various brands of wines

\begin{tabular}{clccc}
\hline $\begin{array}{c}\text { Sample } \\
\text { No. }\end{array}$ & \multicolumn{1}{c}{ Wine Name } & $\begin{array}{c}\text { Tannin } \\
\text { content, } \%\end{array}$ & $\begin{array}{c}\text { Free sulfur } \\
\text { dioxide, ppm }\end{array}$ & $\begin{array}{c}\text { Total sulfur } \\
\text { dioxide, ppm }\end{array}$ \\
\hline 1 & Napoleon Port wine No.7 & 0.0283 & 12.5 & 96 \\
2 & Jagermeister & 0.0766 & 5.12 & 256 \\
3 & Santa Barbara Vinho Porto & 0.0799 & 5.12 & 128 \\
4 & Sula Vineyards & 0.1381 & 5.12 & 96 \\
5 & Jacob's Creek & 0.0299 & 5.12 & 80 \\
6 & Yellow Tail Merlot & 0.0249 & 7.82 & 78 \\
7 & Lavina's port wine No.5 & 0.0199 & 12.34 & 64 \\
8 & Charlet Red & 0.2041 & 5.18 & 156 \\
9 & Angove & 0.2091 & 6.38 & 104 \\
10 & Vinsura & 0.2506 & 4.78 & 98 \\
11 & 10\% Premium & 0.1079 & 7.98 & 102 \\
12 & Port Wine Monte Carlo & 0.0166 & 8.28 & 94 \\
\hline
\end{tabular}


Estimation of tannin concentration was performed by oxidation of tannins present in the wine sample with standard potassium permanganate using indigo carmine indicator. This is simple and more accurate method for determination of tannins content in wine samples. The potassium permanganate is strong oxidizing agent, it oxidizes the alcohol and other substances present in the wine sample. For this reason it is necessary to remove alcohol from wine sample by gentle heating. The blank sample must be prepared by treating wine sample with activated charcoal to remove the tannins and pigments present in wine.

Ripper method on the other hand is simple iodine titration method most commonly used for determination of sulfur dioxide ${ }^{17}$. It produces quick results and is also simple and inexpensive method. In this method iodine reacts with sulfur dioxide to give sulfuric acid and hydrogen iodide.

$$
\mathrm{SO}^{2}+\mathrm{I}_{2}+2 \mathrm{H}^{2} \mathrm{O} \rightarrow \mathrm{H}_{2} \mathrm{SO}_{4}+2 \mathrm{HI}
$$

In this method standardized iodine solution was added to the wine sample. Sulfur dioxide and water present in wine sample react with iodine. Sulfuric acid and hydrogen iodide are formed until iodine consumed. Starch indicator is used to indicate blue color at the end point of titration. In wine, sulfur dioxide is in equilibrium between different forms viz total $\mathrm{SO}_{2}$, free $\mathrm{SO}_{2}$ and molecular $\mathrm{SO}_{2}$. The sugar and other carbon compounds present in wine are able to act as sulfur dioxide binding. $\mathrm{SO}_{2}$ can also bind with phenolic compounds of red wine and reaction is directly visible by decoloration. Sulfur dioxide prevents chemical and enzymatic oxidation of wine. The results of sulfur dioxide contents for various wine samples are shown in Table 1. This experimental data shows that total sulfur dioxide content in the wine are in the range 64 to $256 \mathrm{ppm}$ while free sulfur dioxide content of wines are in the range of 4.78 to 12.5 i.e. lower side. The findings of total sulfur dioxide are in the range which is given by European and Indian standard however free sulfur dioxides contents are slightly at lower side of European standard ${ }^{13,18}$.

\section{Conclusion}

The present study shows the data for tannins and sulfur dioxide content of various types of wine samples. Experimental results show tannin content is in the range of 0.016 to $0.25 \%$. In case of dark colored wines, tannin content is on higher side while colorless wines represent low tannins content. On the other hand, free $\mathrm{SO}_{2}$ content in the wine sample is in the range of 4.78 to $12.5 \mathrm{ppm}$ while total $\mathrm{SO}_{2}$ content are in the range of 64 to $256 \mathrm{ppm}$ both free and total $\mathrm{SO}_{2}$ content are in the range as given by European and Indian standard.

\section{Acknowledgement}

The authors are very grateful to the former director Dr. M. K. Malve and present director B. B. Daundkar for their kind support to carry the research work.

\section{References}

1. Oberholster A and Bedryfsbiblioteek S, Wynboer, 2003, (165), 64-68.

2. Lina M, Ramirez-Lopez and Cristina A M Dewitt, Food Science and Nutrition, 2014, 2(5), 470-477.

3. Atkins P W, Molecules, New York, Scientific American Library Series, 1987.

4. Ribereau-Gayon P, Glories Y, Meujean A and Dubourdieu D, Handbook of enology. The chemistry of wine stabilization and treatment, Vol 2, John Wiley and sons New York, 1998.

5. Scalbert A, Johnson I T and Saltmarsh M, Am J Clin Nutri., 2005, 81(1), 215S-217S. 
6. $\quad$ Sims C A and Morris J R, Am J Enol Vitic., 1986, 37(2), 163-165.

7. Chunk T K, Tit Y W, Cheng I W, Yao W H and Yuan L, Crit Rev Food Sci Nutri., 1998, 38(6), 421-464; DOI:10.1080/10408699891274273

8. Swain T and Hillis W E, J Sci Food Agri., 1959, 10(1), 63-68; DOI:10.1002/jsfa.2740100110

9. Folin O and Ciocaltue V, J Biol Chem., 1927, 73, 627-650.

10. Martin L P, Steve V S and Larry G B, J Agric Food Chem., 1978, 26(5), 1214-1218; DOI:10.1021/jf60219a031

11. Porter L J, Hrstich L N and Chan B C, Phytochem, 1986, 25(1), 223-230; DOI:10.1016/S0031-9422(00)94533-3

12. Selinger B, Chemistry in the marketplace, $4^{\text {th }}$ Edition, London: Hartcourt Brace Jovanovich, 1989.

13. Jackowetz N, Li E and de Orduna R M, Research Focus, Carnell Viticulture and Enology Program, 2011-3.

14. Somers T C, Tech Rew Aust Wine Res Inst., 1990, 67, 3-10.

15. Puech JL, Feuillat F and Mosedale J R, Am J Enol Vitic., 1999, 50(4), 469-478.

16. Lerno L, Reichwage M, Ponangi R, Hearne 1, DE Block and Oberholster A, Am J Enology Viticulture, 2015, 66(4), 444-453.

17. Fowles G W A, Education Chem., 1978, 3, 89.

18. European Commission Regulation, 2014, (EU). 59/2014. 